\title{
OBITUARIES
}

\section{Prof. David Keilin, F.R.S.}

Prow. Karlin died suddenly in Cambridge on February 27. Born on March 21, 1887, in Moscow, where his parents were residing temporarily at that time, he returned to Poland as a child and spent his school days in Warsaw. With the graduation certificate of Górski's High School, he left Warsaw to seek education abroad, first in Liège, and next in Paris.

It was in Paris, under the guidance of Maurice Caullery, to whom he became deeply attached, that Keilin first acquired a keen interest in parasitology and cellular biology in general. Parasitic protozoa, nematodes, and insects, their morphology, physiology, and life-cycles, formed the chief area of his researches until 1925, that is, right up to the time of the discovery of cytochrome. Some 60 publications, many of them in French, date from that period, including his D.Sc. (Paris) dissertation, and the well-known papers on the discovery of the life-cycle in the fly Pollenia rudis, the larvæ of which develop parasitically in the earthworm Allolobophora chlorotica.

The outbreak of the First World War found Keilin in France, but shortly afterwards he received an invitation to join Prof. G. H. F. Nuttall in the capacity of research assistant in the University of Cambridge. He arrived in England in February 1915, and remained in Cambridge, except for brief journeys to the Continent, for the rest of his life, being prevented from more extensive travels by chronic asthma, a troublesome ailment from which he was seldom free, which, however, he never once permitted to interfere with either his work or his strikingly cheerful and optimistic outlook on life and people in general. He became Beit Memorial Research Fellow in 1920, University lecturer in parasitology in 1925, and successor to Nuttall, as Quick professor of biology, and director of the Molteno Institute of Biology and Parasitology in 1931.

In 1925, Keilin discovered cytochrome. His paper "On Cytochrome, A Respiratory Pigment, common to Animals, Yeast and Plants", published in the Proceedings of the Royal Society, revolutionized cellular biology and biochemistry. It now became feasible to follow by direct spectroscopic observation, in a characteristically simple yet elegant manner, the intracellular respiration of intact cells, be they those of the Gastrophilus larvæ, an insect's wing muscles, or a suspension of yeast. The 'indophenol oxidase' was shown to be a cytochrome oxidase, and the 'charcoal-iron models' of an earlier ora were put in their proper perspective. The impact of Keilin's findings on later developments in cellular biology is best attested by the fact that after the passage of forty years there is scarcely an issue of any journal devoted to modern cellular physiology or biochemistry without major contributions on the nature and function of the cytochrome pigments, denoting a remarkably long-lasting influence scarcely surpassed by other scientific discoveries of our times.

Good fortune gave me a chance to join Keilin in 1935. His main line of research then was the purification of cytochrome $c$, and he was also making extensive comparative studies of certain hæmoproteins, enjoying all the time the faithful collaboration of Dr. E. F. Hartree. The Molteno Institute of that period was an exceptionally congenial and stimulating milieu for scientists, both young and old. The professor, always clad in his white laboratory coat and most actively participating in experimental work himself, was surrounded by colleagues converging on the 'Molteno' from every corner of the world, seeking his advice, guidance and heart-warming friend- ship. The discussions ranged from the kinetics of this or that newly purified enzyme to intricate parasitological problems under investigation by Drs. P. Tate and A. Bishop, and several other outstanding parasitologists. Of the investigations happily pursued with Keilin, those which stand out in my memory most vividly are the discovery, in 1936, of the complex of the plant-peroxidase with its substrate, hydrogen peroxide, and, in the years that followed, the purification of polyphenol oxidase and lacease from plants, and hæmocuprein and carbonic anhydrase from red blood cells, the latter two proteins being a source of particular joy to us, on account of the beautiful crystalline form of the blue copper-protein, and the identification of carbonic anhydrase as the first known zinc-containing enzyme.

Catalase was another enzyme in which Keilin was greatly interested, he and Hartree being responsible for the discovery of the so-called coupled oxidation, which depends on the peroxidatic function of that enzyme. Throughout these and subsequent studies on catalase, peroxidase, cytochrome, succinic oxidase, glucose oxidase and hæmoglobin, which were described in some 200 publications, Keilin's extraordinarily acute sense of observation was not only impressive but also invaluable, as was his amazingly wide knowledge of biology of both the plant and animal kingdom. Studying the hæmoglobin of the nodules in leguminous plants he discovered that the plant alone, or the symbiotic micro-organism Rhizobium by itself, are incapable of forming hæmoglobin, and that this ability is acquired only in symbiosis. The presence of hæmoglobin was also demonstrated by him in yeast, moulds and in certain protozos. Much of the work on the detection of traces of hæmoproteins in the various cells was due to the skilful utilization of the spectroscopic technique which Keilin was able to refine considerably in 1949 , when he discovered that absorption spectra of hæmoproteins can be greatly intensified by lowering the temperature.

David Keilin was not only a brilliant scientist but also a man of great culture and the finest human qualities. Of small stature, but energetic, and incredibly kind-hearted (Szent-Györgyi once described him as a "small man with a big heart"), he was always accessible to all, colleagues and students alike, ready to listen, advise and offer help and encouragement. His lectures were a delight to attend; he prepared them meticulously, always including elaborate demonstrations of actual experiments carefully prepared and rehearsed. Modesty was another of his outstanding characteristics. When several of us, his pupils, begged him on his retirement from the professorship to sanction the preparation of a Festschrift, he declined in no uncertain terms because he believed that a Festschrift could turn out to be a time-consuming burden to the contributors. Keilin received many honours, including the fellowship of the Royal Society (1928), the Royal Medal (1939) and Copley Medal (1951) of the Royal Society; he was elected to the corresponding membership (1947) and associate membership (1955) of the Académie de Sciences in Paris; to the American Academy of Arts and Sciences in Boston (1959) and the Polish Academy of Sciences in Warsaw (1959); ho held honorary doctorates of the Universities of Brussels, Bordeaux, Liège and Utrecht. These various honours, however, he would mention rarely. Whenever in conversation the question came up as to what would bring him real pleasure, his answer invariably was: a successful experiment !

The fate of the Molteno Institute which he dearly cherished was ever close to his heart, and plans for its continued welfare and development may well have been among his last thoughts. To those who, like the Rocke- 
feller Foundation, have been supporting the researches of the Institute for many years he was truly grateful. One must also sincerely hope that he was not unaware of the profound and lasting affection with which he filled the hearts of all those who have had the good fortune of being associated with him. To his widow, Dr. Anna Keilin, and daughter, Dr. Joan Keilin, goes out the sympathy of scores of devoted friends, all of whom share with them the sadness of their bereavement. Their sense of irreparable loss may be partly lightened in the near future when Dr. Joan Keilin accomplishes the publication of her father's nearly completed book which deals with many aspects of his researches.

T. MANN

\section{Prof. Anna Weizmann}

Prof. Anna Weizmann, professor emeritus in the Weizmann Institute of Science, Israel, died on February 16 in Rehovoth.

It was in the summer of 1938 , while on a visit to EretzIsrael, that I first met Anna Weizmann. I had returned to Palestine for the first time in twelve years on a pilgrimage long deferred. For me, this return was overflowing with the excitement and emotional impact of witnessing the impressive record of development in the homeland after an absence of more than a decade.

One morning I came to the Daniel Sieff Research Institute, a scientific outpost and oasis amidst a patchwork quilt of sandy desolation flanked by citrus-groves. Anna was among the first to whom I was introducod. I had heard of her by repute, the 'Chief's' younger sister, who had followed him into the field of organic chemistry; but I was not prepared for her charm and dry humour, the acid wit that stamped her as a Weizmann, the easy, affable manner of one who was so fully adjusted to her scientific environment.

I cannot recall the gist of our initial conversation, but as I mot and spoke with her in the downstairs laboratory that she was to occupy for so many years, until she moved into the 'Chief's' own laboratory after his death, I formed an instant liking and attachment that grew over the next quarter-century.

The Weizmann family had a remarkable record. Every one of the twelve sons and daughters had gone into some skilled profession as the younger ones followed in the footsteps of the elder. Chemistry, medicine, engineeringin each of these vocations a Weizmann brother and sister had found dedicated fulfilment. Anna, like her elder brothers Chaim and Moshe, of the Hebrew University, had chosen the field of chemistry; and the value of her work on plant fermentations, and later in compiling the first contributions to a record of medicinal plants in Israel, was reflected in her numerous papers which appeared in the world's scientific journals.

After Dr. Chaim Weizmann's death, she devoted herself to maintaining the family's scientific tradition in circumstances which were saddened by the death of her brothers and sisters, Moshe, Yechiel (Chillik) and Haya Lichtenstein; and, the last blow of all that struck at her failing health, the passing of Chillik's widow Yehudit (Ida), mother of General Ezer Weizmann, ehief of the Israel Air Force.

The one ray in her life in the midst of these many sad bereavements was the arrival from the U.S.S.R. in 1956 of her younger sister Masha, a doctor of medicine, and her husband.

Anna Weizmann was the last living link with the Weizmann scientific tradition; and, as part of it, her own contribution will be for ever remembered.

Meyer W. Weisgal

\section{Captain A. Ritscher}

THE death is announced from Hamburg of Captain Alfred Ritscher at the age of eighty-four. In his long career as a research worker in polar regions two events stand out most.

In 1912 he commanded the vessel of the SchröderStranz Expedition to Spitsbergen waters, and to him goes the credit of saving its members after the ship was wrecked on the north coast of the Island. Ritscher trudged alone for seven days across the icy wastes in order to fetch help from the mining settlement of Longyearbyn. This very exacting experience in no way damped his ardour for polar research, and in 1938 he lod the German Schwabenland Expedition to the Antarctic. In the course of it, wide areas of the Antarctic continent were mapped by aerial photogrammetry, and ranges of mountains earlier unknown were discovered from the air. In the years following the Second World War, Ritscher devoted himself to working up the scientific results of the expedition, and among the honours which came to him for his nautical and scientific achievements were the Grand Cross for service to the Bundesrepublik, and the Kirchenpauer Medal of the Geographical Society of Hamburg.

\section{NEWS and VIEWS}

\section{The Royal Society: Research Professorships}

Folsowing the announcement by the Royal Society of the appointment of Prof. G. H. Beale to the first of the new Royal Society research professorships which have been established with financial support from the Governmont (Nature, 197, 1252; 1963), it has been announced that the second holder of a Royal Society research professorship will be Prof. R. H. Dalitz, at present professor of physics in the University of Chicago. Prof. Dalitz, who is distinguished for his contributions to nuclear theory and the physics of elementary particles, will work in the Department of Theoretical Physics at the Clarendon Laboratory, Oxford, and be known as "Royal Society Research Professor at Oxford University".

\section{Leverhulme Visiting Professors to India}

IN October of last year the Royal Society and the Leverhulme Trust announced the establishment of a scheme for the appointment of two visiting professors to visit a university or research institution in India each year for a period of about four months. The Royal Society and the Leverhulme Trust have now announced the first two appointments of visiting professors to go to India during October-March 1964: Prof. R. D. Haworth, who retires this year as Firth professor of chemistry and head of the Chemistry Department in the University of Sheffield, will visit the University of Madras as visiting professor in the field of organic chemistry; Prof. H. S. Lipson, professor of physics in the Faculty of Technology of the University of Manchester, will visit the University of Calcutta as visiting professor in the field of physics.

\section{Professor of Chemistry, The Royal Institution of Great Britain : $\quad$ Prof. G. Porter, F.R.S.}

Prof. G. Porter has been elected professor of chemistry at the Royal Institution. Prof. Porter, who is professor of physical chemistry at the University of Sheffield, a post he has held since 1955, is also to succeed Prof. R. D. Haworth as Firth professor of chemistry and head of the Department of Chemistry at Sheffield, as from 